\title{
MLL/ELL Fusion Gene
}

National Cancer Institute

\section{Source}

National Cancer Institute. MLL/ELL Fusion Gene. NCI Thesaurus. Code C101057.

A fusion gene that results from a chromosomal translocation $t(11 ; 19)(q 23 ; p 13.1)$ which fuses the first 7 exons of the MLL gene to most of the coding sequence of the ELL gene. This rearrang ement is associated with treatment-related acute myeloid leukemia. 